\title{
Defisiensi Riboflavin dan Demensia pada Usia Lanjut
}

\author{
Riboflavine Deficiency and Dementia in Elderly
}

\section{Idral Purnakarya}

Program Studi Ilmu Kesehatan Masyarakat Fakultas Kedokteran Universitas Andalas

\begin{abstract}
Abstrak
Demensia Alzheimer menempati urutan kesembilan penyebab kematian di Amerika Serikat. Demensia adalah kondisi yang sering dialami yang berhubungan dengan berbagai faktor dan gaya hidup terutama diet. Penelitian ini bertujuan untuk mengetahui hubungan defisiensi asupan riboflavin (vitamin B12) dengan demensia pada usia lanjut (usila). Penelitian ini menggunakan desain studi cross sectional dan dilaksanakan pada bulan September 2007 sampai dengan Januari 2008. Sampel penelitian adalah 141 lansia berumur lebih dari sama dengan 60 tahun yang diambil secara purposive sampling. Demensia diukur menggunakan kuesioner MMSE ( $\leq 24$, skor maksimum 30 ) dan asupan riboflavin diukur menggunakan form Semi Quantitative - FFQ. Penelitian ini memperlihatkan bahwa $47,5 \%$ usila mengalami demensia. Hasil uji statistik menunjukkan bahwa terdapat hubungan yang signifikan antara umur, tingkat pendidikan, dan asupan riboflavin dengan kejadian demensia pada usila (nilai $p<0,05$ ).
\end{abstract}

Kata kunci: Demensia, defisiensi riboflavin, usia lanjut

\footnotetext{
Abstract

Dementia Alzheimer's was ranked the ninth leading cause of death in The United States. Dementia can not be avoided as related to several factors and lifestyle especially the diet. The objective of this research is to know relation the deficiency of riboflavine (vitamin B12) intake and incidence of dementia at elderly. A cross-sectional study was conducted between September 2007 and January 2008. The sample obtained was 141 elderly which it was conducted to purposive sampling. Dementia was measured by using questionnaire MMSE $(\leq 24$, maximum score was 30$)$, and riboflavine intake was measure by Semi Quantitative - FFQ form. This study shows that dementia in elderly was $47,5 \%$. Statistical test showed that Statistical test showed that incidence of dementia had significantly associated with ages, level of education, and riboflavine intake ( $p$ value $<0,05$ ).

Key words: Dementia, deficiency of riboflavine, elderly
}

\section{Pendahuluan}

Demensia Alzheimer menempati urutan kesembilan penyebab kematian di Amerika Serikat. ${ }^{1}$ Tahun 2007, Alzheimer's Association melaporkan bahwa sekitar 13\% atau 1 dari 8 usia lanjut (usila) berumur 65 tahun ke atas menderita demensia. Setiap 72 detik, seseorang akan mengalami Alzheimer di negara Amerika Serikat, sedangkan pada pertengahan abad mendatang bertambah satu orang mengalami alzheimer setiap 33 detik. ${ }^{2}$ Demensia merupakan suatu kondisi penurunan dan gangguan kognitif meliputi penurunan kemampuan mengingat dan berpikir, gangguan perilaku, dan mood. Selama proses penuaan, demensia tidak dapat dihindari karena berkaitan dengan berbagai faktor gaya hidup terutama diet. ${ }^{3}$ Berbagai faktor yang berperan menyebabkan seseorang berisiko menderita demensia antara lain meliputi genetis, umur, jenis kelamin, tingkat pendidikan, dan defisiensi atau kekurangan riboflavin (vitamin B12).3,4

Hasil penelitian menunjukkan bahwa seseorang dengan keluarga yang mempunyai riwayat demensia berisiko lebih tinggi daripada yang tidak mempunyai riwayat demensia. Umumnya, peningkatan prevalensi demensia terjadi bersamaan dengan pertambahan umur dan peningkatan umur harapan hidup. Persentase usila di Indonesia meningkat dari 6,3\% pada tahun 1992 menjadi 7,9\% pada tahun 2002 dengan umur harapan hidup meningkat dari 65,4 tahun pada tahun 2000 menjadi 66,4 tahun pada tahun 2002. Selain itu, usila yang berpendidikan rendah lebih berisiko mengalami penu-

Alamat Korespondensi: Idral Purnakarya, Program Studi Ilmu Kesehatan Masyarakat FK Universitas Andalas, Jl. Perintis Kemerdekaan Padang 25127, Hp.081363270696,e-mail: idral_pkarya@yahoo.com 
runan kognitif dan demensia. ${ }^{4-6}$

Defisiensi riboflavin sering dialami oleh para usila. Kadar serum riboflavin dalam darah bisanya dijadikan tanda untuk menentukan seseorang mengalami demensia. Selain itu, penderita demensia pada umumnya dilakukan pengobatan terhadap kekurangan riboflavin. Para ahli mengemukakan secara biologis ada 2 mekanisme yang menyebabkan konsentrasi riboflavin rendah dan menyebabkan demensia. Pertama, riboflavin merupakan faktor penting bagi metilasi homosistein menjadi metionin. Defisiensi riboflavin menyebabkan peningkatan konsentrasi plasma homosistein. Peningkatan konsentrasi plasma homosistein tersebut dihubungkan dengan peningkatan prevalensi penurunan kognitif serta peningkatan risiko perkembangan demensia dan penyakit Alzheimer. Kedua, kadar serum riboflavin yang rendah dapat mengakibatkan berkurangnya ketersediaan kelompok metil di otak. Kondisi tersebut akhirnya dapat mengakibatkan gangguan pembentukan mielin, berbagai neurotransmiter dan membran fosfolipid. Meskipun secara biologis hubungan kausalitas memungkinkan, di sisi lain hubungan antara riboflavin dengan penurunan kognitif masih kontroversial. ${ }^{7}$ Berdasarkan fakta-fakta tersebut maka penelitian ini bertujuan untuk mengetahui hubungan defisiensi asupan riboflavin dengan demensia pada usila.

\section{Metode}

Desain penelitian yang digunakan pada penelitian ini adalah cross sectional, dilakukan pada 141 usila berumur $\geq 60$ tahun yang memenuhi kriteria inklusi dan dilaksanakan sejak bulan September 2007 hingga Januari 2008 di wilayah Jakarta Barat. Sampel diambil dari 11 perkumpulan usila yang ada dan diperoleh 3 perkumpulan berbeda dengan jumlah usila terbanyak yaitu 1 pos pembinaan terpadu (posbindu), 1 panti wreda, dan 1 perkumpulan vegetarian. Pemilihan sampel dilakukan secara purposive sampling. ${ }^{8}$ Untuk responden yang mengalami demensia, dibutuhkan responden pendamping dengan kriteria menjadi pendamping bagi usila minimal selama 6 bulan serta berperan menyiapkan dan menyajikan makanan bagi usila. Demensia pada usila diukur menggunakan kuesioner Mini Mental State Examination (MMSE) dengan total skor 30 melalui wawancara dengan responden dan observasi. Hasil pengukuran dikategorikan dengan melihat skor MMSE yang diperoleh yaitu demensia apabila skor MMSE $\leq 24$ dan tidak demensia apabila skor MMSE $>24.9-10$

Karakteristik responden diperoleh menggunakan kuesioner melalui wawancara dengan responden atau pendamping responden. Data asupan riboflavin diperoleh melalui wawancara dengan responden atau pendamping responden menggunakan form Semi Quantitative Food Frequency Questionnaire (FFQ), 11 dibantu dengan food model untuk mengonversikan satuan ukuran rumah tangga menjadi satuan gram. Data asupan riboflavin yang dikumpulkan dihitung dengan software nutrisoft dan dibandingkan dengan angka kecukupan gizi (AKG) tahun 2004 bagi penduduk Indonesia. ${ }^{2}$ Selanjutnya, asupan riboflavin dikategorikan menjadi kurang (asupan $<100 \%$ AKG) dan cukup (asupan $\geq 100 \%$ AKG). Analisis dilakukan secara bertahap yaitu analisis univariat dan bivariat. ${ }^{13}$ Analisis univariat untuk melihat distribusi frekuensi dari variabel yang diteliti. Analisis bivariat menggunakan uji chi square dengan derajat kepercayaan $95 \%(\alpha=0,05)$.

\section{Hasil}

\section{Analisis Univariat}

Hasil analisis penelitian terhadap 141 responden menemukan prevalensi usila yang mengalami demensia sebesar $47,5 \%$ dan rata-rata skor MMSE usila adalah $23,16 \pm 5,84$. Berdasarkan karakteristik responden, ditemukan $65,2 \%$ adalah usila perempuan, berumur $60-69$ tahun $(59,6 \%)$, dan sekitar $65,3 \%$ berpendidikan SMP atau lebih rendah. Penelitian ini juga menemukan hampir dua pertiga usila $(65,2 \%)$ mengalami kekurangan asupan riboflavin dan rata-rata asupan riboflavin usila adalah $2,22 \pm 0,86 \mu \mathrm{g} /$ hari atau setara dengan 91,67\% AKG (Lihat Tabel 1). Rata-rata umur usila demensia adalah $70,03 \pm 7,19$ tahun dan untuk usila tidak demensia adalah 66,08 \pm 5,28 tahun. Penelitian ini juga menunjukkan bahwa rata-rata asupan riboflavin usila yang mengalami demensia $(2,09 \pm 0,54 \mu \mathrm{g} / \mathrm{hari})$ lebih rendah dibandingkan usila yang tidak mengalami demensia $(2,34$ \pm 1,05 $\mu \mathrm{g}$ /hari) (Lihat Tabel 2).

\section{Analisis Bivariat}

Hasil uji statistik terhadap 141 reponden menunjukkan bahwa terdapat hubungan yang signifikan antara umur usila (nilai p < 0,05; odds ratio $(\mathrm{OR})=3,79$ ), tingkat pendidikan (nilai $\mathrm{p}<0,05$; $\mathrm{OR}=14,10$ ), asupan riboflavin (nilai $\mathrm{p}<0,05$; $\mathrm{OR}=6,35$ ) dengan kejadian

Tabel 1. Distribusi Demensia, Karakteristik Responden, dan Riboflavin

\begin{tabular}{llll}
\hline Variabel & Kategori & $\mathbf{n}$ & $\%$ \\
\hline Status demensia & Demensia & 67 & 47,5 \\
& Tidak demensia & 74 & 52,5 \\
Umur & $>69$ tahun & 57 & 40,4 \\
\multirow{3}{*}{ Jenis kelamin } & $60-69$ tahun & 4 & 59,6 \\
\multirow{2}{*}{ Tingkat pendidikan } & Laki-laki & 49 & 34,8 \\
& Perempuan & 92 & 65,2 \\
& Tidak tamat SD & 51 & 36,2 \\
& Tamat SD & 30 & 21,3 \\
\multirow{3}{*}{ Riboflavin } & Tamat SMP & 11 & 7,8 \\
& Tamat SMU & 23 & 16,3 \\
& Perguruan tinggi & 26 & 18,4 \\
& Kurang & 92 & 65,2 \\
& Cukup & 49 & 34,8 \\
\hline
\end{tabular}


Tabel 2. Distribusi Rata-rata Umur, Skor MMSE, dan Riboflavin

\begin{tabular}{llll}
\hline \multirow{3}{*}{ Variabel } & \multicolumn{3}{c}{ Nilai Rata-rata } \\
\cline { 2 - 4 } & Semua Lansia & Lansia Demensia & Lansia Tidak Demensia \\
\hline Umur (g) & $67,96 \pm 6,55$ & $70,03 \pm 7,19$ & $66,08 \pm 5,28$ \\
MMSE & $23,16 \pm 5,84$ & $18,15 \pm 4,58$ & $27,69 \pm 1,59$ \\
Riboflavin $(\mu \mathrm{g})$ & $2,22 \pm 0,86$ & $2,09 \pm 0,54$ & $2,34 \pm 1,05$ \\
\hline
\end{tabular}

Tabel 3. Hubungan antara Karakteristik Responden dan Riboflavin dengan Demensia

\begin{tabular}{|c|c|c|c|c|c|c|c|c|c|}
\hline \multirow{3}{*}{ Variabel } & \multirow{3}{*}{ Kategori } & \multicolumn{6}{|c|}{ Demensia } & \multirow{3}{*}{ Nilai $p$} & \multirow{3}{*}{ OR $(95 \% \mathrm{CI})$} \\
\hline & & \multicolumn{2}{|c|}{ Ya } & \multicolumn{2}{|c|}{ Tidak } & \multicolumn{2}{|c|}{ Total } & & \\
\hline & & $\mathbf{n}$ & $\%$ & $\mathbf{n}$ & $\%$ & $\mathbf{n}$ & $\%$ & & \\
\hline \multirow[t]{2}{*}{ Umur } & $>69$ tahun & 38 & 66,3 & 19 & 33,7 & 57 & 100,0 & \multirow[t]{2}{*}{$0,0005^{*}$} & 3,79 \\
\hline & $60-69$ tahun & 29 & 34,5 & 55 & 65,5 & 84 & 100,0 & & $(1,86-7,72)$ \\
\hline \multirow[t]{2}{*}{ Jenis kelamin } & Laki-laki & 25 & 51,0 & 24 & 49,0 & 49 & 100,0 & \multirow[t]{2}{*}{0,667} & 1,24 \\
\hline & Perempuan & 42 & 45,7 & 50 & 54,3 & 92 & 100,0 & & $(0,62-2,48)$ \\
\hline \multirow[t]{2}{*}{ Pendidikan } & Rendah & 61 & 66,3 & 31 & 33,7 & 92 & 100,0 & \multirow[t]{2}{*}{$0,0005^{*}$} & 14,10 \\
\hline & Tinggi & 6 & 12,2 & 43 & 87,8 & 49 & 100,0 & & $(5,41-36,73)$ \\
\hline \multirow[t]{2}{*}{ Riboflavin } & Kurang & 57 & 62,0 & 35 & 38,0 & 92 & 100,0 & \multirow[t]{2}{*}{$0,0005^{*}$} & 6,35 \\
\hline & Cukup & 10 & 20,4 & 39 & 79,6 & 49 & 100,0 & & $(2,82-14,31)$ \\
\hline
\end{tabular}

Keterangan : *signifikan (nilai $\mathrm{p}<0,05$ )

demensia. Prevalensi demensia lebih banyak diderita oleh usila yang berumur 70 tahun ke atas $(66,3 \%)$ dibandingkan dengan usila yang berumur $60-69$ tahun. Prevalensi demensia yang dialami usila laki-laki lebih banyak dibandingkan usila perempuan. Secara umum, prevalensi usila yang mengalami kekurangan asupan riboflavin menderita demensia 3 kali lebih besar dibandingkan usila yang cukup asupan riboflavin (Lihat Tabel 3).

\section{Pembahasan \\ Demensia}

Prevalensi demensia pada penelitian ini sedikit lebih rendah daripada hasil penelitian Handajani, ${ }^{10}$ pada usila di Daerah Khusus Ibu Kota (DKI) Jakarta $(62,5 \%) .{ }^{15}$ Rata-rata skor MMSE penelitian ini lebih rendah $(23,16$ $\pm 5,84)$ jika dibandingkan dengan penelitian yang dilakukan Feng et al, ${ }^{9}$ pada usila Cina di Singapura yang menemukan rata-rata skor MMSE usila 27,9 \pm 1,7. Sebaliknya, lebih tinggi dibandingkan dengan studi epidemiologi yang dilakukan oleh Gillette-Guyonnet et al, ${ }^{14}$ di Toulouse yaitu rata-rata skor MMSE sebesar 16,6 \pm 4,9 , dan studi prospektif Guerin et al, ${ }^{15}$ di Toulouse sebesar $17,2 \pm 5,9$.

Sebagian besar umur usila yang mengalami demensia berada pada kisaran 60 - 69 tahun. Hal tersebut tidak jauh berbeda dengan penelitian Feng et al, ${ }^{9}$ di Singapura, Handajani, 10 di Jakarta, dan Yudarini et al, 16 di Indonesia. Kecenderungan ini disebabkan oleh umur harapan hidup Indonesia tahun 2005 yaitu 69 tahun. ${ }^{17}$ Penelitian ini menemukan hubungan yang signifikan antara umur dengan demensia pada usila. Rata-rata usila yang mengalami demensia berumur 70,03 tahun dan yang tidak mengalami demensia berumur 66,08 tahun (nilai $\mathrm{p}<$ $0,05)$. Temuan ini sama dengan hasil penelitian Rahardjo et al, ${ }^{18}$ di Indonesia yang menemukan ada hubungan signifikan antara umur dengan demensia. Prevalensi demensia akan meningkat bersamaan dengan pertambahan umur. ${ }^{3,19}$ Usila umumnya mengalami penurunan berat otak, pada usia 90 tahun berat otak akan berkurang $10 \%$ dan jumlah neuron berkurang sekitar 100.000 sel per hari dibanding pada usia muda. 20

Pada penelitian ini sebagian besar usila adalah perempuan $(65,2 \%)$ yang tidak jauh berbeda dengan penelitian sebelumnya. 7,9,10,14,16 Mengingat umur harapan hidup perempuan lebih tinggi daripada laki-laki. Tahun 2005, umur harapan hidup perempuan Indonesia adalah 69 tahun, sedangkan laki-laki adalah 66 tahun. ${ }^{17}$ Tidak ada hubungan yang signifikan antara jenis kelamin dengan demensia (nilai $\mathrm{p}>0,05$ ). Hasil ini sama dengan penelitian di Indonesia sebelumnya yaitu tidak ada hubungan antara jenis kelamin dengan demensia, karena prevalensi demensia pada laki-laki dan perempuan dilaporkan hampir sama. ${ }^{18}$

Pada penelitian ini menemukan tingkat pendidikan berhubungan dengan kejadian demensia, tidak berbeda dengan penelitian Rahardjo et al, ${ }^{18}$ yang menemukan 
hubungan yang signifikan. Penelitian Glymour et al, ${ }^{21} \mathrm{di}$ Amerika Serikat juga menemukan bahwa tingkat pendidikan berhubungan secara signifikan dengan skor kognitif setiap tahun. Begitu pula dengan penelitian Karp et $\mathrm{al}, 22$ di Swedia yang menemukan bahwa usila dengan tingkat pendidikan rendah berisiko mengalami demensia sebesar 2,3 kali dibandingkan usila dengan tingkat pendidikan tinggi (relative risk, $\mathrm{RR}=2,3$; CI $95 \%=1,4$ 3,7). Skor MMSE ditentukan oleh tingkat pendidikan seseorang. Hasil penelitian Yudarini et al, ${ }^{16}$ di Jakarta menemukan bahwa rata-rata skor MMSE usila berpendidikan tinggi lebih besar dibandingkan dengan usila berpendidikan rendah. Keadaan tersebut dibuktikan melalui hasil penelitian ini yaitu sebesar $66,2 \%$ usila berpendidikan rendah menderita demensia. Para peneliti mengungkapkan bahwa pendidikan dapat meningkatkan cadangan otak dengan cara meningkatkan kepadatan sinaptik pada neocortical yang berkaitan dengan korteks. ${ }^{22}$ Usila yang berpendidikan tinggi lebih cenderung mempunyai asupan makanan yang menyehatkan. Usila dengan pola makan sehat lebih menyukai buah, sayur, dan ikan. Horgervost et al, ${ }^{23}$ menemukan bahwa pola makan sehat berhubungan secara signifikan dengan daya ingat.

\section{Asupan Riboflavin}

Penambahan usia berkaitan dengan penurunan kemampuan tubuh untuk mengabsorpsi dan menggunakan riboflavin yang terikat pada protein. ${ }^{24}$ Asupan riboflavin yang rendah berdampak pada defisiensi riboflavin. Defisiensi riboflavin yang rendah dapat merusak proses metilasi yang berperan penting dalam pemeliharaan jaringan otak. Riboflavin dibutuhkan untuk sintesis metionin dan pembentukan S-adenosylmethionine yang berperan sebagai penyumbang metil yang sangat penting bagi pembentukan neurotransmiter, fosfolipid, dan mielin atau jaringan selaput otak. ${ }^{25}$ Analisis lebih lanjut terhadap skor MMSE menghasilkan rata-rata skor MMSE usila dengan defisiensi asupan riboflavin lebih rendah $(21,46 \pm 5,99)$ dibandingkan dengan usila yang cukup asupan riboflavin $(26,35 \pm 3,90)$.

\section{Kesimpulan}

Prevalensi demensia pada usila di wilayah Jakarta Barat cukup besar yaitu 47,5\% dan hampir dua pertiga usila mengalami defisiensi asupan riboflavin. Penelitian ini menemukan ada hubungan yang signifikan antara umur, tingkat pendidikan, dan asupan riboflavin dengan demensia pada usila.

\section{Saran}

Berdasarkan hasil temuan penelitian ini, perlu disarankan kepada Dinas Kesehatan Kota Jakarta Barat untuk mengembangkan program komunikasi, informasi, dan edukasi (KIE) untuk permasalahan usila. Selain itu, perlu diberikan penyuluhan dan penyebaran informasi tentang gizi usila melalui iklan dan leaflet untuk disebarkan pada perkumpulan usila sehingga informasi mengenai pentingnya pemenuhan asupan riboflavin dan asupan zat gizi lainnya secara optimal sehingga dapat mengatasi masalah defisiensi asupan zat gizi pada usila dalam mencapai kesehatan yang optimal.

\section{Daftar Pustaka}

1. Feldman G. Death of a senator: life expectancy and causes of death in 20th century US senators. American Journal of Public Health [seri Internet]. 2003 May [diakses tanggal 30 Mei 2007]; Vol. 93, No.5: [p.771]. Diunduh dari: http://www.ajph.org.

2. Alzheimers Association. Alzheimer's facts and figures 2007. 2007. [diakses tanggal 3 April 2007]. Diunduh dari: http://www.demensia-in-europe.eu/.

3. Campbell TC, Campbell II TM. China study. Dallas: BenBella Book; 2006.

4. Henderson AS. Dementia. Geneva: World Health Organization; 1994.

5. World Health Organization. Mental health: new understanding, new hope. Geneva: World Health Organization; 2001.

6. World Health Organization. The world health report 2003. Shapping the future. Geneva: World Health Organization; 2003.

7. Mooijaart SP, Gussekloo J, Frölich M, Jolles J, Stott DJ, Westendorp RGJ, et al. Homocysteine, vitamin b12, and folic acid and the risk of cognitive decline in old age: the leiden 85-plus study. Am J Clin Nutr. 2005; 82: 866-71. [diakses tanggal 1 Juni 2008]. Diunduh dari: http://www.ajen.org/.

8. Lemeshow S, Hosmer Jr DW, Klar J, Lwanga SK. Besar sampel dalam penelitian kesehatan. Yogyakarta: Gajah Mada University Press; 1997.

9. Feng L, Tse-Pin N, Chuah L, Niti M, Kua E. Homocysteine, folate and vitamin b12 and cognitive performance in older chinese adults: findings from the Singapore longitudinal study. Am J Clin Nutr. 2006; 84: 150612.

10. Handajani YS. Indeks pengukuran disabilitas dan prediksi kualitas hidup pada masyarakat lanjut usia di DKI Jakarta [disertasi]. Depok: Fakultas Kesehatan Masyarakat Universitas Indonesia; 2006.

11. Gibson RS. Principles of nutritional assessment. 2nd ed. New York: Oxfrord University Press; 2005.

12. Lembaga Ilmu Pengetahuan Indonesia, Badan Pusat Statistik, Kementerian Kesehatan, Badan Pengawas Obat dan Makanan, Badan Perencanaan dan Pembangunan Nasional, Kementerian Pertanian, et al. Prosiding Widyakarya Nasional Pangan dan Gizi VIII, Ketahanan Pangan dan Gizi di Era Otonomi Daerah dan Globalisasi. Jakarta: Lembaga Ilmu Pengetahuan Indonesia; 2004.

13. Kleinbaum, Kupper, Muller. Applied regression analysis and other multivariable methods. 2nd ed. Boston: PWS-Kent Publishing Company; 1998.

14. Gillette-Guyonnet S, Nourhashémi F, Andrieu S. Weight loss in alzheimer disease. Am J Clin Nutr. 2000; 71 (suppl): 637S-42S. [diakses tanggal 30 Mei 2007]. Diunduh dari: http://www.ajcn.org/.

15. Guérin O, Andrieu S, Schneider SM, Milano M, Boulahssass R, Brocker $\mathrm{P}$, et al. Different modes of weight loss in alzheimer disease: a prospec- 
tive study of 395 patients, Am J Clin Nutr. 2005; 82: 435-41. [diakses tanggal 1 Juni 2008]. Diunduh dari: http://www.ajcn.org/.

16. Yudarini, Rahardjo TBW, Subarkah, Hogervorst E. Profil sosiodemografi dan status kesehatan lansia di daerah urban dan rural Indonesia. Report on seminar ageing, gender health. Jakarta: Centre for Health Research University of Indonesia; 2008.

17. World Health Organization. World health statistics 2007. Geneva: World Health Organization; 2007.

18. Rahardjo TBW, Yudarini, Subarkah, Dewi VP, Kreager P, Hogervorst E. Mental and social activities and possible dementia among the elderly in three indonesian communities in poster session: spring school on aging oxford institute of ageing. Inggris: University of Oxford; 13-18 April 2008.

19. Alzheimer's Society, LSE, Kings College London. Demensia UK. Summarry of key findings. 2007. [diakses tanggal 3 April 2007]. Diunduh dari: http://www.demensia-in-europe.eu/.

20. Lumbantobing. Kecerdasan pada usia lanjut dan demensia. Jakarta: Balai Penerbit Fakultas Kedokteran Universitas Indonesia; 2006.

21. Glymour MM, Weuve J, Berkman LF, Kawachi I, Robins JM. Baseline adjustment useful in analyses of change? An example with education and cognitive change. Am J Epidemiol. 2005; 162: 267-78. [diakses tanggal 11 Juni 2008]. Diunduh dari: http://www.aje.oxfordjournals.org/.

22. Karp A, Kåreholt I, Qiu C, Bellander T, Winblad B, Laura FL. Relation of education and occupation-based socioeconomic status to incident alzheimer's disease. Am J Epidemiol. 2004; 159: 175-83. [diakses tanggal 11 Juni 2008]. Diunduh dari: http://www.aje.oxfordjournals.org/.

23. Hogervorst E, Sadjimin T, Yesufu A, Kreager P, Rahardjo TB. High tofu intake is associated with worse memory in elderly indonesian men and women, dementia, and geriatric cognitif disorder. S. Basel: Kareger AG; 2008.

24. Morris MS, Jacques PF, Rosenberg IH, Selhub J. Folate and vitamin b12 status in relation to anemia, macrocytosis, and cognitive impairment in older americans in the age of folic acid fortification. Am J Clin Nutr. 2007; 85: 193-200. [diakses tanggal 7 Maret 2007]. Diunduh dari: http://www.ajen.org/.

25. Tucker KL, Qiao N, Scott T, Rosenberg I, Spiro III A. High homocysteine and low b vitamins predict cognitive decline in aging men: the veterans affairs normative aging study. Am J Clin Nutr. 2005; 82: 627-35. [diakses tanggal 1 Juni 2008]. Diunduh dari: http://www.ajcn.org/. 